\title{
New Translocation in Three Generations of a Family
}

\author{
PATRICIA COOKE
}

\author{
With Clinical Notes by \\ A. P. M. PAGE \\ From Centre for Human Genetics, Sheffield 10; and City Hospital, Hucknall Road, Nottingham
}

Edwards et al. (1962) have listed three criteria which make the presumption of reciprocal translocation likely. They are as follows. (1) That at least one chromosome arm of clearly abnormal length should be demonstrated. (2) That the chromosome aberration and the supposedly related abnormality should segregate in a compatible manner. (3) That the likelihood of a causal relation between the observed abnormality in karyotype and abnormality of phenotype is maximized when the phenotypic abnormalities are generalized, congenital, and uncommon.

We describe a case satisfying the above criteria, which has been confirmed by family studies. The presence of the translocation was ascertained from a phenotypically abnormal female child whose family were referred for genetic counselling.

\section{Family Data}

The propositus was the first child of a 21-year-old mother who subsequently gave birth to a normal male child. The mother's family was uncooperative, but, as far as we were able to ascertain, there were no other abnormal individuals or abortions known on her side of the family. The father had an elder brother who was phenotypically normal and a younger sister who had died at the age of 3 days with a cleft palate and rhesus disease. The elder brother had been married twice. The first child of his first marriage was dead at birth, the mother having had severe accidental antepartum haemorrhage with oliguria. The baby had presented as a breech, born as far as the umbilicus on admission. Delivery was swift, and the foetus, which was apparently a normal male, had been dead for some little time as there was early maceration present. The second child of the first marriage and the child of the second marriage were phenotypically normal males born after normal pregnancy and delivery. The paternal grand- $\dot{\omega}$ mother and grandfather were both phenotypically 8 normal. The members of the father's family knew of $\circ$ no abortions or miscarriages (see Fig. 1).

Clinical Description of Propositus. The child $\mathbb{D}$ was clinically examined at each of the following times.

(a) At Birth. The propositus weighed $2062 \mathrm{~g}$. $(4 \mathrm{lb}$. $8 \frac{3}{4} \mathrm{oz}$.) at 40 weeks' gestation. Her length was $46 \mathrm{~cm}$. (18 in.), with a head circumference of $30 \mathrm{~cm}$. (12 in.). The mother had vomited throughout pregnancy. There $\vec{\varphi}$ was a normal vertex delivery but the child was limp anf $\varnothing$ cyanosed at birth. The eyes showed small palpebra fissures and epicanthic folds. There was a right-side्d 'bat' ear. The extremities were cyanosed, the clitoris was enlarged, and there was a single transverse palmar crease in the right hand.

(b) Development. 21st day: regarded as an 'ugly $\stackrel{\varnothing}{\varnothing}$ duckling'. The hands were held as clenched fists. $\overrightarrow{\vec{A}}$ 7 months: signs of spasticity were observed, in all four limbs, with associated mental retardation. There was a

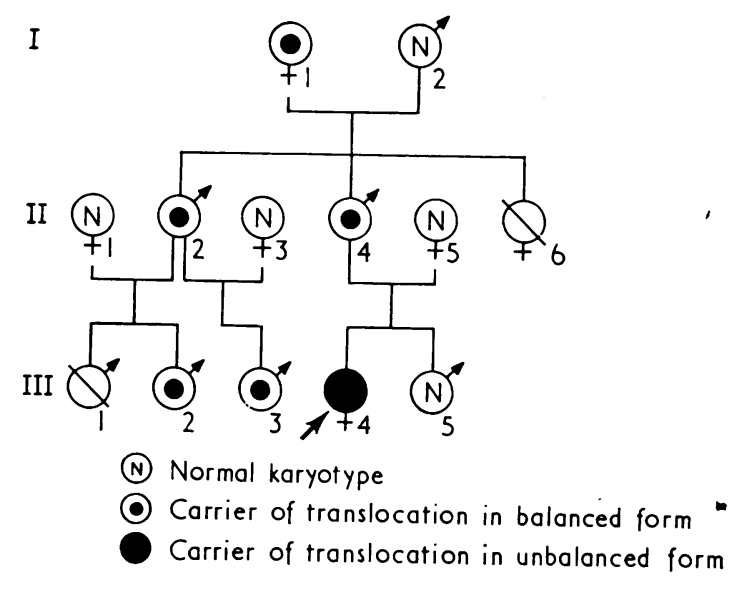

FIG. 1. The family tree. 
soft systolic cardiac murmur. 12 months: still hypertonic, much underweight at $5528 \mathrm{~g}$. (12 lb. $3 \mathrm{oz}$.), and not yet able to sit. 28 months: able to sit but still underweight at $6477 \mathrm{~g}$. (14 lb. $4 \frac{1}{2} \mathrm{oz}$.). A left parasternal systolic cardiac murmur was heard. 42 months: when supported, the child was able to stand and walk. Still underweight at $7597 \mathrm{~g}$. (16 lb. $12 \mathrm{oz}$.). 56 months: when examined at the age of 56 months the patient's weight was low at $8334 \mathrm{~g}$. $(18 \mathrm{lb} .6 \mathrm{oz}$.). There was no speech. She could not walk without support and tended to lean over backwards. The right 'bat' ear and epicanthic folds persisted. All four limbs were slightly spastic, long and thin. She could not fully supinate the forearms. $X$-rays showed the long bones to be abnormally long and thin. There was a praecordial systolic murmur, loudest in the pulmonary area. There was slight clitoral enlargement.

Karyotype Analysis. Samples of peripheral blood were taken from the propositus and 10 other members of her family. Chromosome preparations were made using a modification of the method of Moorhead et al. (1960).

For the 11 individuals studied, 30 cells were counted in each case and of these 10 were fully analysed. All members of the family (Fig. 1) had 46 chromosomes and the paternal grandfather, I.2; mother, II.5; brother, III.5; and both wives, II.1 and 3, of the paternal uncle had normal karyotypes $(46, \mathrm{XX}$ or XY), but in the rest of the family two types of abnormal karyotype were recovered. Type 1 (found in the propositus III.4). In this karyotype there were three chromosomes morphologically like No. 1 , one No. 2, and a normal complement of $\mathrm{X}+6-12 \mathrm{~s}$. All other groups were normal $(46, X X, 2 p+)$ (Fig. 2).

Only one chromosomally similar case has been described (De Grouchy et al., 1963), and it was assumed in that case that the extra No. 1 was the product of a pericentric inversion. Unfortunately, De Grouchy found it impossible to study the whole family and so was unable to confirm or deny the possibility of translocation.

Type 2 (found in the father, II.4, paternal grandmother, I.1, paternal uncle, II.2, and 2 cousins, III. 2 and 3). These individuals carried one extra chromosome, morphologically similar to a No. 1, one No. 2, an extra chromosome morphologically similar to a No. 16, and had a member of the $\mathrm{X}+6-12$ group missing (Fig. 3). This karyotype was interpreted as a reciprocal translocation between a No. 2 chromosome and a member of the $\mathrm{X}+6-12$ group $[46, \mathrm{XX}$ orXY,t $(2 \mathrm{p}+; \mathrm{Cq}-)]$. The abnormal chromosome $(2 \mathrm{p}+)$ carried by the propositus is therefore derived from her father and consists of the larger part of a No. 2 and part of a $C$ group chromosome. The propositus therefore has deletion of the short arm of No. 2 and a duplication of $C$ group autosomal material (Fig. 4).

From the distribution of the three karyotypes (see Fig. 1) it can be seen that the donor chromosome involved cannot be the $\mathrm{X}$ chromosome. For example, in the family of the paternal uncle both children are male; they must, therefore, have received a $\mathrm{Y}$ chromosome from their father, the translocation carrier, but they also carry both translocation products.

Measurement Data. Measurements of total chromatid length were made on the three No. 1 chromosomes, the No. 2, the two No. 3, and the three No. 16 in 42 cells from one of the translocation carriers to determine the following.

(1) The gross amount of chromosomal material exchanged; (2) whether $\mathrm{T} 1$ was separable on the basis of measurement from the normal No. 1 chromosomes;

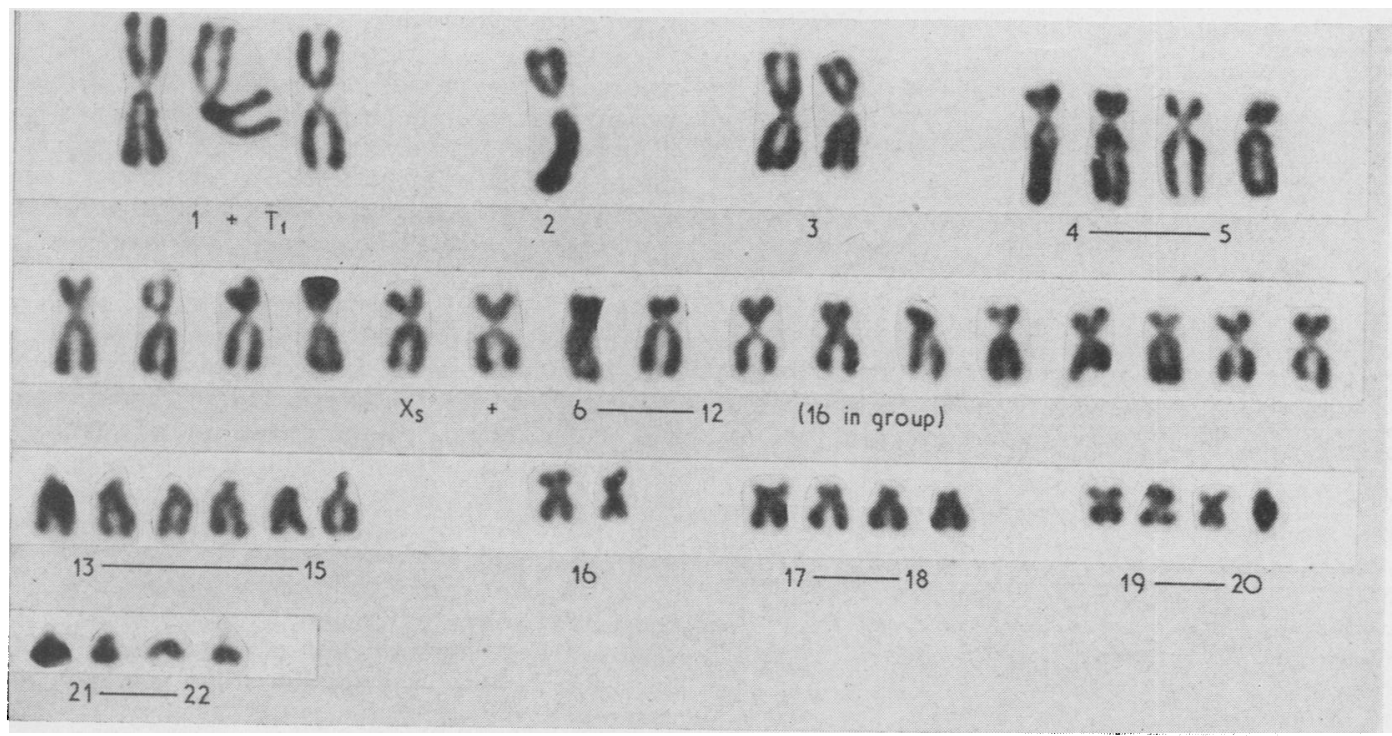

FIG. 2. The chromosome complement of the propositus (III.4). 


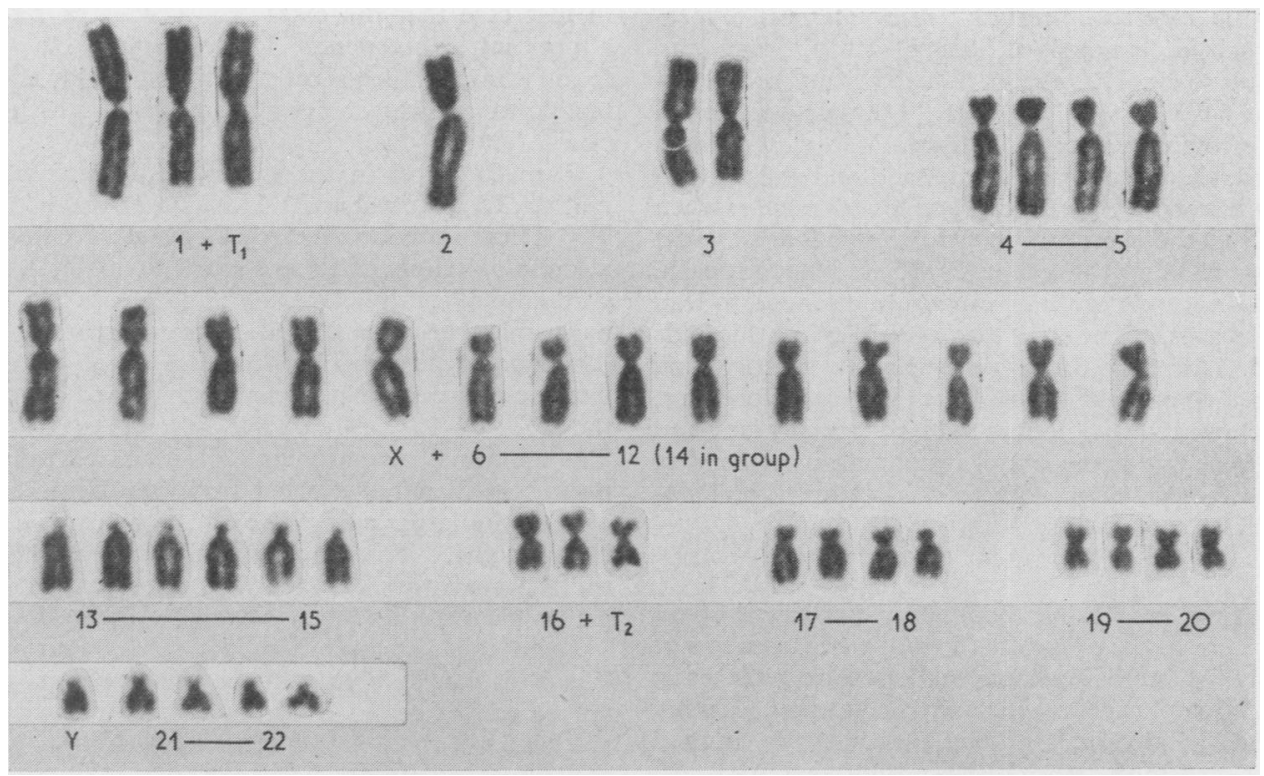

Fig. 3. The chromosome complement of one of the male translocation carriers (II.2).

TABLE I

JOINT REGRESSION ANALYSIS 1+2/3, NORMALS AND ABNORMALS

\begin{tabular}{l|r|r|r|r}
\hline \multicolumn{1}{c|}{ Item } & \multicolumn{1}{c|}{ SS } & df & \multicolumn{1}{c|}{ MS } & \multicolumn{1}{c}{ VR } \\
\hline Over-all regression & 9632.9582 & 1 & 9632.96 & $\star \star \star \star$ \\
Difference in position & 142.4725 & 1 & 142.47 & 9.61 \\
Difference in slope & 25.7624 & 1 & 25.76 & 1.74 NS \\
Combined residual & 1303.7635 & 88 & 14.82 & \\
\hline Total variation & 11104.9566 & 91 & & \\
\hline
\end{tabular}

$\star \star \mathrm{p} 0.01-0.001$

$\star \star \star \star \mathrm{p}<0.001$

NS, not significant.

Adjusted mean value $1 \mathrm{~s}+\mathrm{T}_{1}+2$ (abnormals) $=62 \cdot 9 \mu$.

Adjusted mean value $1 \mathrm{~s}+2 \mathrm{~s}$ (normals) $=60 \cdot 2 \mu$.

$$
\text { Difference }=2.7 \mu \text {. }
$$

\section{TABLE II}

JOINT REGRESSION ANALYSIS. BIGGEST No.1/RECONSTITUTED TRANSLOCATION PRODUCT MEAN REST 1s/RECONSTITUTED TRANSLOCATION PRODUCT

\begin{tabular}{c|r|r|r|r}
\hline Item & \multicolumn{1}{|c|}{ SS } & df & \multicolumn{1}{c|}{ MS } & \multicolumn{1}{c}{ VR } \\
\cline { 1 - 2 } $\begin{array}{c}\text { Combined regression } \\
\text { Difference in regression }\end{array}$ & $\begin{array}{r}695 \cdot 9616 \\
42.0491\end{array}$ & 1 & $\begin{array}{r}695.96 \\
42.05\end{array}$ & $10 \cdot 31 \star \star$ \\
Combined residual & $326 \cdot 1497$ & 80 & 4.08 & \\
\hline $\begin{array}{c}\text { Total variation within } \\
\text { groups }\end{array}$ & $1064 \cdot 1604$ & 82 & & \\
\hline
\end{tabular}

$$
\begin{aligned}
& \star \star \star \mathrm{p} 0.01-0.001 \\
& \star \star \star 0 \\
& \mathrm{p}<0.001
\end{aligned}
$$

b (Biggest No. 1/Reconst. trans)

b (Rest 1s/Reconst. trans)

$=1 \cdot 0897 \pm 0 \cdot 1136$ Expected slope $=1$ No significant difference.

$=0.7963 \pm 0.0889$ Expected slope $=1$ p $0.05-0.01$.
(3) whether T2 was separable on the basis of measurement from the normal No. 16; and (4) the original size of the 'donor' chromosome.

For comparison, similar measurements were made ond 10 cells from each of 5 normal subjects.

A joint regression analysis was carried out to compare the size of the 4 largest chromosomes in the translocation carrier $(1 \mathrm{~s}+\mathrm{T} 1+2)$ with the 4 largest normal chromosomes (No. $1+$ No. 2 ), using the size of the No. 3 chromosomes as a correcting covariate. The results of the analysis are given in Table I. There is a difference in adjusted mean values significant at the $1 \%$ level. The difference between the adjusted means, $2.7 \mu$, is an estimate of the average resultant length of chromatin exchanged. An addition of such magnitude to a No. 2 chromosome (average size $15 \cdot 4 \pm 2 \cdot 3 \mu$ ) produces a chromosome of approximately $18 \mu$-at the upper end of the No. 1 range (average size $16.4 \pm 2.4 \mu$ ) $T_{1}$ is therefore more likely to be the largest of the 3 apparent No. 1s in any cell. This hypothesis was tested by joint regression analysis (Table II), comparing the size of the largest apparent No. 1 in any cell and the means of the other two No. 1s with the size of a No. 2 chromosome to which $2.7 \mu$ had been added. As expected, the largest apparent No. 1 was related to the reconstituted translocation chromosome by a line which did not differ significantly from No. 1, whereas the relation between the other two No. $1 \mathrm{~s}$ and the reconstituted translocation chromosome was significantly different from No. 1 .

From a similar set of analyses it was shown that $T_{2}$ was most likely to be the smallest of the apparent No. 16s (Table III). The mean size of the smallest 16 in abnormal cells $=4.6 \mu$; an addition of $2.7 \mu$ would give an estimate of the size of the 'donor' chromosome as $7 \cdot 3 \mu$. The 6-12 group chromosomes in normal subjects range 
TABLE III

JOINT REGRESSION ANALYSIS 16/3, NORMALS AND ABNORMALS

\begin{tabular}{l|r|r|r|r}
\hline \multicolumn{1}{c|}{ Item } & \multicolumn{1}{c|}{ SS } & d.f. & MS & \multicolumn{1}{c}{ VR } \\
\hline Over-all regression & $58 \cdot 2862$ & 1 & $58 \cdot 29$ & $\star \star \star$ \\
Difference in position & $15 \cdot 1114$ & 1 & 15.11 & $\vdots \star 0 *$ \\
Difference in slope & 1.0688 & 1 & 1.07 & $4.46 \star$ \\
Combined residual & 21.0930 & 88 & 0.24 & \\
\hline Total variation & 95.5594 & 91 & & \\
\hline
\end{tabular}

$\star$ p $0.05-0.01$.

$\star \star \star \mathrm{p}<0.001$.

Adjusted mean size of $16 \mathrm{~s}+\mathrm{T}_{2}$ (abnormals) $=5 \cdot 2 \mu$.

Adjusted mean size of $16 \mathrm{~s}$ (normals) $=6.1 \mu$.

in size from approximately 7-12 $\mu$. Either some material has been lost, or the donor chromosome must have been one of the smallest 6-12s.

Buccal Smear and $\mathbf{X}$ Chromosome Analysis. Four counts of 30 cells were made on a buccal smear from the propositus. Not only was the count significantly higher than normal (Table IV), but the bodies appeared larger than usual. Measurements of the size of the body were made randomized with normal female smears. The sex chromatin body from the propositus was significantly larger $(p=0.1-0.05)$ than the normal sex chromatin body (Table IV).

Cultures of blood from the propositus and her mother were long labelled with tritiated thymidine (Bishop and Bishop, 1963) to examine the size of the late-labelling $\mathbf{X}$ chromosome at metaphase. A control series was available in which the late-labelling $X$ chromosome had been measured in 5 cells from each of 7 normal females (Bishop, Leese, and Blank, 1965). An analysis showed (Table V) that the $\mathrm{X}$ chromosome of the propositus at metaphase was no larger than normal.

\section{TABLE V}

\section{ANALYSIS OF X CHROMOSOME LENGTH}

Mean normals $=4.71 \mu$; Mean propositus $=4.49 \mu$; Mean mother $=$

$5 \cdot 19 \mu$ Variation between normal subjects $=2.4283$

S.E. diff. between normals and either propositus or mother

$$
=\frac{2.4283}{7}+\frac{2.4283}{1}=1.67
$$

t (N v propositus) 6 d.f. $=\frac{4 \cdot 71-4.49}{1 \cdot 67}=0.13$ not sig.

$t\left(\mathrm{~N} v\right.$ mother) 6 d.f. $=\frac{4 \cdot 71-5 \cdot 19}{1.67}=0.29$ not sig.

\section{Discussion}

The propositus in this case showed duplication for part of the long arm of a member of the 6-12 group, together with possible deletion of part of the short arm of a No. 2. The gross amount of translocated material was of the order of $2.7 \mu$. Segregation from a quadrivalent of the type shown in Fig. 4 could result in 6 gametic types (ignoring discordant
TABLE IV

t TEST-COUNTS: ANALYSIS OF VARIANCE, SIZE OF SEX CHROMATIN BODY

\begin{tabular}{l|r|r|r|r}
\hline \multicolumn{1}{c|}{ Item } & SS & d.f. & MS & VR \\
\hline Normals and abnormals & $0 \cdot 757$ & 1 & $0 \cdot 76$ & $5 \cdot 1 \star$ \\
Between slides (normals) & $0 \cdot 446$ & 5 & $0 \cdot 09$ & \\
Between slides (abnormals) & $0 \cdot 864$ & 4 & $0 \cdot 22$ & \\
Pooled between slide variation & $1 \cdot 310$ & 9 & $0 \cdot 15$ & \\
Pooled within slide variation & $1 \cdot 515$ & 99 & 0.02 & \\
\hline Total variation & 4.892 & & & \\
\hline
\end{tabular}

$\star \mathrm{p} 0 \cdot 1-0.05$.

Mean count, normal females, 12; mean count propositus, 17; S.C. Diff., $1 \cdot 27$; t (30), 3.9; p 0.001.

orientation and crossing over in an interstitial region). The 4 most probable gametes are shown in Fig. 4. The remaining $2\left(22^{\mathrm{c}}\right.$ and $\left.\mathrm{C} \mathrm{C}^{2}\right)$, which result from adjacent homologous segregation, have not been recovered, nor has the $2 \mathrm{C}^{2}$ gamete which is complementary to $2^{\mathrm{c}} \mathrm{C}$ gamete. This may be inviable.

Though there was no significant difference from normality in the size of the metaphase X chromosome, the sex chromatin body was significantly larger than normal, a difference presumably due to some sort of behavioural upset connected with the unbalanced genotype.

The only cytologically comparable case was that of De Grouchy. A clinical comparison was therefore made between the two cases, the results of which were summarized in Table VI.

The clinical features of the two cases were dissimilar, the main differences being that the propositus in the present case was grossly underweight, spastic, and retarded, as opposed to De Grouchy's case with normal weight, hypotonia, and only slight retardation.

There appeared to be no clinical abnormalities

TABLE VI

COMPARISON OF CLINICAL FEATURES

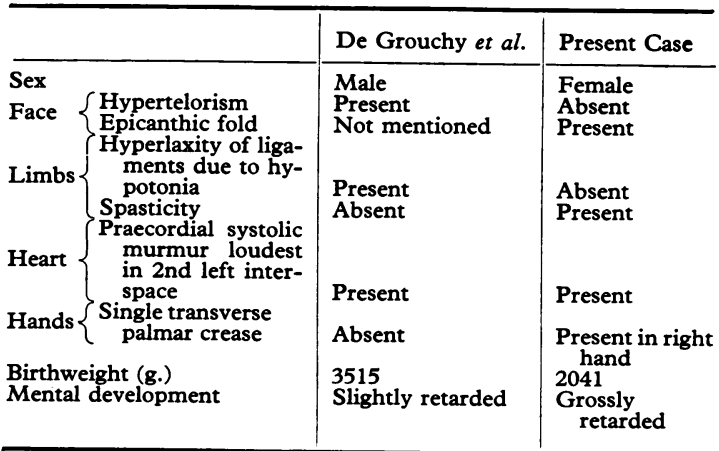




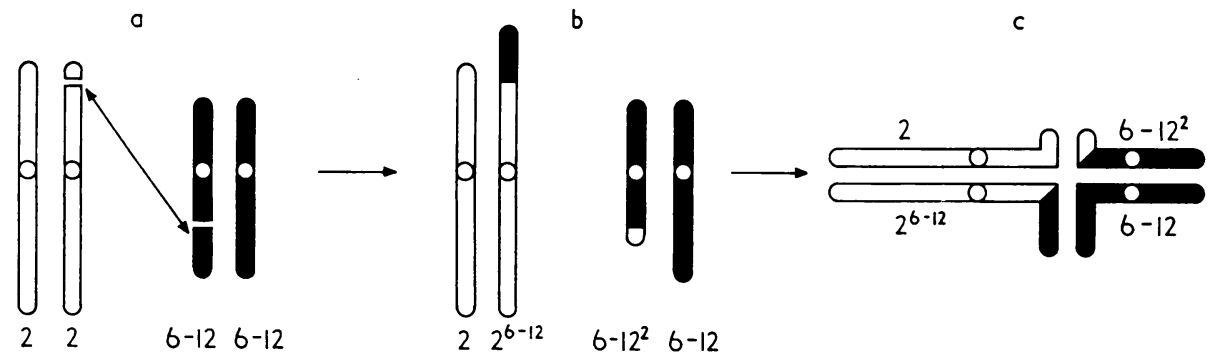

\begin{tabular}{|c|c|c|c|c|}
\hline \multirow{2}{*}{ Gametes } & \multicolumn{4}{|c|}{ Heterozygote } \\
\hline & $2,6-12$ & $2,6-12^{2}$ & $2^{6-12}, 6-12$ & $2^{6-12}, 6-12^{2}$ \\
\hline $\begin{array}{c}\text { Basic } \\
2,6-i 2\end{array}$ & $\begin{array}{c}2,2,6-12,6-12 \\
\text { Basic } \\
\text { Homozvgote } \\
2 n=46\end{array}$ & $\begin{array}{c}2,2,6-12,6-12^{2} \\
\text { Not recovered } \\
\text { (Presumed inviable) } \\
2 n=46\end{array}$ & $\begin{array}{l}2,2^{6-12}, 6-12,6-12 \\
\text { Propositus } \\
\text { Partial trisomy } 6-12 \\
\text { Partial monosomy } 2 \\
\qquad 2 n=46\end{array}$ & $\begin{array}{l}2,2^{6-12}, 6-12,6-12^{2} \\
\text { Translocation carrier } \\
\text { of normal phenotype } \\
\qquad 2 n=46\end{array}$ \\
\hline
\end{tabular}

Fig. 4. The suggested derivation and transmission of the translocation. (a) Shows presumptive break positions. (b) Shows balanced heterozygote. (c) Shows pairing in pachytene in the balanced heterozygote. Only the four most probable gametic types from the balanced heterozygote are shown.

in the translocation carriers, so it is unlikely that any chromatin has been lost. With such a small family it is difficult to make any comment about the distribution of the different karyotypes. Of the 6 living products of carrier matings, 4 are carriers, 1 is normal, and 1 has an unbalanced karyotype. The karyotypes of the 2 dead children are unknown. Though the ratio of carriers to non-carriers $(4: 1)$ seems high, as does the proportion of balanced to unbalanced (5:1), neither differ significantly from the $1: 1$ ratio which would be theoretically expected, unless such factors as gametic, or embryonic, selection were acting.

\section{REFERENCES}

Bishop, A., and Bishop, O. N. (1963). Analysis of tritium labelled human chromosomes and sex chromatin. Nature (Lond.), 19g0 930.

, Leese, M., and Blank, C. E. (1965). The relative length ande를 arm ratio of the human late-replicating $\mathrm{X}$ chromosome. $\boldsymbol{F}$. med Genet., 2, 107.

Edwards, J. H., Fraccaro, M., Davies, P., and Young, R. B. (1962). Structural heterozygosis in man: analysis of two families with a note on dermal ridge configurations by $L$. S. Penrose and S. B. Holt. Ann. hum. Genet., 26, 163.

De Grouchy, J., Emerit, I., Corone, P., Vernant, P., Lamy, M., and Soulie, P. (1963). Inversion pericentrique probable du chromosome no 2 et malformations congénitale chez un garçon. Ann. Génét., 6, 21.

Moorhead, P. E., Nowell, P. C., Mellman, W. J., Batipps, D. M., and Hungerford, D. A. (1960). Chromosome preparations of leucocytes cultured from human peripheral blood. Exp. Cell Res., 30, 613. 